\title{
Legal Regulation of Remote Work in Russia
}

\author{
M. A. Andrianova ${ }^{(\bowtie)}$ \\ Moscow State Institute of International Relations (University) of the Ministry \\ of Foreign Affairs, Moscow, Russia \\ m. andrianova@inno.mgimo.ru
}

\begin{abstract}
Labor law in Russia is expected to change in order to make this sphere more attractive to employers, more accessible to employees, and more effective for the state. The practice meets expectations of optimists for the implementation of progressive reforms, which also affect problems of the labor regulation. Business has long been interested in using this tool, but the lack of skills in new technologies among a wide range of employees and the inertia of the current legislation hindered the process. Currently, there is a clear tendency to overcome all the indicated obstacles to the widespread use of remote work in Russia. This article investigates the current legislation and practice of the remote work application, recent changes in the sphere, as well as development trends in the remote work regulation, taking into account the changing needs of the population.
\end{abstract}

Keywords: Interaction of labor and civil law in Russia $\cdot$ Labor law reform in Russia $\cdot$ Registration of labor contracts with employees $\cdot$ Remote work · Technology impact on labor law

\section{Introduction}

At the end of the XVIII century. the increased use of collective labor in the first industrial enterprises led to a paradoxical situation: the state was interested in the industrial development; industry and entrepreneurs needed to use labor; people needed to work. But relations regulated in terms of the long-established principle of freedom of contract (which has always worked well as a natural regulator) stalled.

As a result, all participants were dissatisfied: employees were suffocating from appalling working conditions, employers were dissatisfied with the quality of work and the constant threat of aggravation of relations at the enterprise, the state expected a social explosion.

Labor law arose and formed as an independent branch at that time when all participants in labor management relations came to the conclusion that the situation could not remain so it was. It is interesting that employers and large industrialists initiated the creation of a special regulation of labor relations at enterprises They were the first to realize that the society had reached a new stage of its development.

It seems that labor law is currently experiencing something similar. More and more people talk about the need for reforms in the sphere of regulation of labor relations [9], 
and there are opinions that the traditional idea of employment - a 40-h working week, mandatory presence in the office - is becoming outdated [8].

It is much more effective to give more freedom to the employer in choosing the form of employment that he is ready to provide, and more freedom to the employee in matters of regulating the labor regime, switching to remote employment. The ongoing technological changes also have a strong impact on the process of performing the labor function. Representatives of many professions can perform their work from anywhere in the world, if they have access to the Internet and a laptop or smartphone.

Even before the coronavirus pandemic, this fact meant that the growth of the number of remote workers around the world, the development of flexible forms of employment re trends of the near future. Currently, the advantages of remote work and the need for it are undeniable. When the peak of the pandemic is passed, the trace effect of the months of work experienced on the remote mode will continue to affect and will inevitably correct the attitude of the legislator to this institution.

\section{Methodology}

To solve the research tasks, the author used both general scientific methods: dialectical method, methods of analysis and synthesis, and special methods of legal science: formal legal method, comparative legal method, historical legal method, methods of grammatical and logical interpretation of legal norms. A structural and functional method was used in relation to the development of trends in the field of labor law in Russia. These methods allowed us to create a more complete and comprehensive view of the considered problem.

\section{Results}

At present, we have successfully passed the time when the very possibility of recognizing relations using remote technologies as labor relations was denied. The question was raised by the freedom of the employee from the direct control of the employer arising from the use of remote work. Now we are talking about expanding the scope of labor law to non-standard areas, including remote work and relations in the field of professional sports.

Such positive changes (for the purposes of this study, we consider it appropriate to focus on changes dedicated to remote work), which could be compared with a small revolution in the field of labor law, occurred in 2013, when the text of the Labor Code was added with Chapter 49.1 "Specific features of regulating the work of remote workers" [12]. Similar changes have been made to labor regulations in many foreign countries. In particular, "telework" has been considered in the Labor Code of France, starting from the Article L1222-9 [11].

Part 1 of Article 312.1 of the Labor Code of the Russian Federation provides an official definition of remote work, which is recognized as the performance of a certain function of the employment contract outside the location of the employer [12]. In general, it is not currently possible to say that the issue of remote work is not legally 
regulated. An employment contract with a remote employee can be concluded by exchanging electronic documents. This situation has significantly facilitated the practice of hiring remote workers, but the situation is far from ideal at the moment.

A mandatory condition for electronic document management, which is clearly established by law, is the use of enhanced qualified electronic signatures of the parties to the employment contract when exchanging electronic documents. The enhanced qualified electronic signature is the strictest type of electronic signature in the opinion of the legislator [5]. Using only such a signature will eliminate problems for the parties with proof of the existence of an employment relationship between them.

Remote work relations that are registered with violations may not give the parties protection under the Labor Code [12]. For example, the Definition of the Moscow City court in 2017 stated that an employment contract concluded between parties, as it follows from the requirements of Article 312.1 of the labor code of the Russian Federation, with the inclusion of a condition for remote work, signed by both the plaintiff and the defendant, is not concluded. However, the presence of electronic correspondence between the parties does not indicate the remote nature of the work [4].

There are obvious difficulties faced by the practice with an overly formal approach to regulating relations within the framework of the labor legislation. In addition to the difficulties that arise at the stage of registration of labor relations, there are issues related to the proper performance of labor duties by the employee.

A lot of researchers and practitioners draw attention to the lack of control available to the employer. It seems that remote mode is not suitable for all forms of employment, but if the employer initially assumes this possibility, the main problem is not the lack of ability to control employees, but ensuring effective communication with them and the ability to receive timely results of high-quality work. This goal can be achieved by more detailed procedures and conditions for interaction between the employee and the employer, including by defining the procedure for obtaining assignments, reporting procedures, technical capabilities for rapid communication between the parties, and so on.

In itself, the possibility of more detailed regulation of labor relations within the framework of individual labor contracts is another trend and urgent need of modern labor law. Judicial practice convinces parties of the need (for security purposes) to use standard labor contracts and other typical documents in the framework of labor relations, however, only individualized labor contracts can give a sense of vividness and effectiveness the labor law, which is so necessary for all the parties.

Continuing to cite examples of unpleasant complications that parties face when using remote work, we will cite several court decisions.

According to the Appeal ruling of the Sverdlovsk regional court of 14.08.2018, if the personnel department is located in one city, and the dismissed employee is in another, the employer should ensure that the employee's work recordbook is issued on the day of dismissal at his place of work [2]. This harmless definition reveals a problem of possible abuse by employees, as well as contradictions between the document management requirements in relation to labor relations in paper form, while the relationship between the parties is based on remote interaction. In the above case, the claim was filed by an employee who considered that the work record book was issued to him untimely and won the dispute. Taking into account the ongoing transition to electronic 
workbooks, it seems that this practice can also have a positive impact on solving problems of registration of hiring and firing of remote employees.

Another difficult practical problem is a possibility of combining traditional employment and remote work. Based on the analysis of court decisions, we have to conclude that the practice does not allow such a combination [1].

There are problems with determining grounds for dismissal of remote employees. In particular, an employee cannot be dismissed for his absence at the workplace if he performed their work remotely based on the agreement with the employer. This conclusion was reached by the Supreme Court of the Russian Federation in the Definition of 16.09.2019 N 5-KG19-106 [3].

It seems that the Definition was made because of the fact that the agreement between parties did not specify how the parties would carry out the communication necessary in the opinion of the employer for the effective performance of the employment function. In our opinion, an employee's violation of the agreements established in the contract may give a completely different picture in court.

It should be noted that the legislation and legal practice of foreign countries on the considered subject also do not imply that the regulation of remote work has reached its highest development level. The reforms in the sphere of labor law that have been carried out in France in recent years also relate to issues of remote workers. The French legislator proposes collective agreements as the main regulation source of this type of labor relations and establishes in the law a list of issues to be discussed during negotiations. Among them, there are conditions for transferring an employee to "télétravail" and terminating the transfer agreement, provisions concerning methods and the procedure for expressing consent to the transfer, provisions on working hours, frequency of communication and working hours, and the employment regime for persons with disabilities. Thus, two tasks are solved at once. The appropriate method of regulation is proposed, taking into account the specifics of a particular enterprise, which removes the task of the legislator to regulate areas that can not be subject of effective state regulation. A list of issues is also proposed, that are the most difficult from the point of view of the subsequent implementation of relations.

We can conclude that the legal regulation of remote work in Russia currently needs special attention and gentle adjustment. It should also be taken into account that the use of remote work significantly expands the possibility of protecting the employees' rights, is an effective means of combating unemployment and staff turnover, seasonal epidemics and force majeure, and indicates the socially-oriented nature of the regulation norms. However, in such legal relations, the employer is a weak side, which bears both the problem of the inability to implement full control over the employee's compliance with the labor discipline, and all the difficulties associated with the legal uncertainty of registration and notification of employees.

\section{Discussion}

Currently, there is no shortage of articles on practical issues related to the use of remote work, which give advice to employers on the correct registration of employees, their proper notification, taking into account a significant number of recent bylaws. 
However, there are few academic papers on the considered subject. Examples include the work of Lyutov "Remote work: The experience of the European Union and the problematic aspects of its legal status in Russia" [7] and Shuraleva "Distance work: A comparative analysis of the laws of the EAEU member states" [10]. Both works draw attention to the lack of regulation in this sphere.

This position could be accepted if it were not the obvious impossibility to regulate thoroughly the use of remote work at the legislative level. Clarification is required, but in view of the obvious trend away from a centralized regulation. It is necessary to make more active use of local acts and collective agreements in order to create the most effective and flexible labor regulation.

\section{Conclusion}

The text of this article has collected examples of practical difficulties when using distance labor. In our opinion, it would be wrong to conclude that the considered institute is not viable in Russia. On the contrary, it is precisely such non-standard forms that can give a positive impetus to the effective application of institutions of such an ingenious invention as labor law, which is now completely undeservedly perceived by the parties as an unnecessary burden.

A possible solution to this problem is to abandon the formal approach practiced by the parties in the formation and registration of labor relations in general, and distance labor in particular. It would also be wrong to assume that, in the end, labor law aims at a complete transition to flexible and atypical forms of employment, such as distance work. Flexible forms of employment (temporary work, distance work, and loan work) do not replace traditional employment, but are intended to complement it.

It is only important that these forms are recognized by the legislator and effectively protected in the courts. World practice shows that there is a direct correlation between the effectiveness of legislation on flexible forms of employment and the level of informal employment in the country.

It seems that the state authorities of the Russian Federation also feel the need to choose a more liberal approach to regulating atypical forms of employment in general, and remote work in particular. An example is a letter from the Ministry of Labor dated March 2020 [6]. According to the Letter, a transfer to a remote (distant) job is allowed as a temporary measure without a special reissue of the employment contract. It is necessary to obtain the consent of the employee, the wording of which can be included in the order for temporary transfer to remote work. The employee has to be familiar with the order. It is also needed to make an additional agreement.

We can hardly hope that the procedural nature and algorithmization of labor relations will soon weaken its influence in practice. In the end, these features of the legal technique of labor law were conceived to facilitate the situation for employees in case of violation of their rights. For a similar purpose - more complete realization of the interests of employees, the institute of remote work was also conceived. 


\section{References}

1. Appeal ruling of the Moscow city court of 04.04.2019 in the case N 33-14969/2019. http:// www.consultant.ru/cons/cgi/online.cgi?req=doc\&ts $=112059073108725661762668853 \&$ cacheid=503D9F4BB8CC611F982BF4E35478E9C3\&mode=splus\&base=SOCN\&n=1127 700\&rnd=60135401FA2DC70E4A13661EF422A9C7\#xe7ziah0xq. Accessed 07 May 2020

2. Appeal ruling of the Sverdlovsk regional court of 14.08.2018 in the case N 33-14260/2018. http://www.consultant.ru/cons/cgi/online.cgi?req=doc;base=RASVR;n=160666; dst= 100053\#011187480356378776. Accessed 07 May 2020

3. Definition of 16.09.2019 N 5-KG19-106. https://legalacts.ru/sud/opredelenie-sudebnoikollegii-po-grazhdanskim-delam-verkhovnogo-suda-rossiiskoi-federatsii-ot-16092019-n-5kg19-106/. Accessed 07 May 2020

4. Definition of the Moscow city court of 14.04.2017 N 4G-2443/2017. http://www.consultant. $\mathrm{ru} /$ cons/cgi/online.cgi?req $=$ doc\&base $=S O C N \& n=855332 \# 06766297269837012$. Accessed 07 May 2020

5. Federal law of 06.04.2011 N 63-FZ (as amended on 23.06.2016) "About an electronic signature" (from ed. and add., Intro. effective from 31.12.2017). http://www.consultant.ru/ document/cons_doc_LAW_112701/. Accessed 07 May 2020

6. Letter of the Ministry of Labor of 27.03.2020 N 14-4/ 10/P-2741. http://www.consultant.ru/ document/cons_doc_LAW_348752/. Accessed 07 May 2020

7. Lyutov, N.L.: Remote work: the experience of the European Union and the problematic aspects of its legal status in Russia. Lex Russica 10(143), 30-39 (2018)

8. Munz, A.: Social innovation and the work of the future. HR Digest 14, 5-7 (2019)

9. Orlovsky, YuP: Is labor law reform necessary? Law 11, 39-46 (2019)

10. Shuraleva, S.V.: Distance work: a comparative analysis of the laws of the EAEU member states (part 1). Labor law Russia Abroad 4, 41-44 (2019)

11. The Labor Code Of France. https://www.legifrance.gouv.fr/affichCode.do?cidTexte= LEGITEXT000006072050. Accessed 22 May 2020

12. The Labor Code of the Russian Federation of 30.12.2001 N 197-FZ (as amended on 16.12.2019). http://www.consultant.ru/document/cons_doc_LAW_34683/. Accessed 07 May 2020 